\title{
STUDI NUMERIK UMUR KELELAHAN (FATIGUE LIFE) PADA PROPELLER KAPAL PENANGKAP IKAN DENGAN KAPASITAS MESIN 24 HP
}

\section{Rizqi Ilmal Yaqin', Angger Bagus Prasetiyo², Pristiansyah ${ }^{3}$, Muhammad Haritsah Amrullah $^{4}$, Binsar Maruli Tua Pakpahan ${ }^{5}$}

\author{
${ }^{1}$ Program Studi Permesinan Kapal, Politeknik Kelautan dan Perikanan Dumai \\ ${ }^{2}$ Jurusan Teknik Mesin, Institut Tekologi Nasional Yogyakarta \\ ${ }^{3,4}$ Jurusan Teknik Mesin, Politeknik Manufaktur Negeri Bangka Belitung \\ ${ }^{5}$ Jurusan Teknik Mesin, Universitas Negeri Medan \\ Email: ${ }^{1}$ r.ilmalyaqin@politeknikkpdumai.ac.id
}

\begin{abstract}
Abstrak
Propeller merupakan bagian dari komponen kunci pada propulsi kapal penangkap ikan. Hal tersebut dikarenakan propeller dapat memberikan momentum pada fluida yang dapat menjadi gaya dorong pada kapal. Namun, beberapa kejadian yang ada di wilayah Kota Dumai mendapatkan adanya kegagalan pada propeller sebelum waktunya. Diduga adanya beban berlebih pada model propeller tersebut sehingga umur kelelahan dari propeller menjadi rendah. Disisi lain, perkembangan teknologi yang pesat dapat mesimulasikan suatu model desain untuk mencari kegagalan yang terjadi. Finite Element Analysis adalah salah satu solusi desainer untuk mengetahui umur kelalahan suatu model dan daerah rawan kegagalan pada suatu model. Penelitian ini menggunakan data model propeller dari kapal penangkap ikan di Tempat Pelelangan Ikan Kota Dumai yang selalu mengalami kegagalan sebelum waktunya. Bahan yang digunakan yaitu paduan tembaga. Sedangkan gambar model menggunakan Autodesk Inventor dan simulasi Finite Element Analysis menggunakan software ANSYS R17.2 dengan jumlah nodes model sebesar 51108 dan number of elemen dari model sebesar 26268. Hasil yang didapatkan dari penelitian ini yaitu tegangan Von Mises pada model simulasi yaitu sebesar 613,33 MPa sampai 0,01164 MPa. Sedangkan nilai deformasi karena pengaruh pembebanan pada model yaitu $5,3657 \mathrm{~mm}$ hingga $0 \mathrm{~mm}$. Hasil tersebut mempengaruhi dari umur kelelahan (fatigue life) pada model dengan nilai $10^{9}$ yang paling tinggi dan 0 yang paling rendah. Hasil dari nilai umur kelelahan pada model mempengaruhi hasil tingkat kerusakan dan angka keamanan model dengan nilai beruturut turut yaitu $10^{32}$ hingga 1 dan 15 hingga 0,32446. Sehingga dapat dikatakan propeller akan terjadi kegagalan sebelum waktunya.
\end{abstract}

Kata Kunci: Propeller, Umur Kelelahan, tegangan Von Mises, Finite Element Analysis

\begin{abstract}
Propeller is part of a key component in fishing boat propulsion. Propeller can provide momentum to the fluid which can be a thrust on the ship. However, The failure of the propeller found prematurely. The failure of the propeller maybe because of overload on the propeller model so the fatigue life of the propeller becomes low. On the other hand, the rapid development of technology can simulate a design model to look for failures that occur. Finite Element Analysis is one of the designer solutions to determine the age of failure of a model and failureprone areas in a model. This study uses propeller model data from fishing boat with engine 24HP in Dumai City TPI that always fail prematurely. The material used is copper alloy. While the drawing model uses Autodesk Inventor and Finite Element Analysis simulation using ANSYS R17.2 software with the number of model nodes is 51108 and the number of elements of the model is 26268. The results obtained from this study are Von Mises stress on the simulation model that is equal to $613.33 \mathrm{MPa}$ to $0.01164 \mathrm{MPa}$. While the deformation value due to the effect of loading on the model is 5,3657 $\mathrm{mm}$ to $0 \mathrm{~mm}$. These results affect the age of fatigue (fatigue life) on the model with the highest value 109 and the lowest 0 . The results of the fatigue life value on the model affect the results of the level of damage and the safety number of the
\end{abstract}


model with successive values of 1032 to 1 and 15 to 0.32446 . The conclusion of the result is the propeller will fail prematurely.

Keywords: Propeller, Fatigue Life, Safety Factor, Finite Element Analysis

\section{PENDAHULUAN}

Kapal ikan adalah kapal yang memiliki fungsi yang utama dalam menangkap ikan di perairan. Bagi negara kepulauan yang memiliki jumlah perairan $3 / 4$ dari luasan negara tersebut yaitu seluas $5,9 \mathrm{~km}^{2}$ (Lasabuda, 2013) dan didukung jumlah sumber daya perairan yang sangat besar menyebabkan pentingnya pemanfaatan sumber daya perairan tersebut. Indonesia adalah salah satu negara yang memiliki jumlah sumber daya peraiaran yang sangat banyak. Beberapa masyarakat pesisir di Indonesia memiliki profesi sebagai nelayan sehingga kebutuhan adanya kapal penangkap ikan sangat penting. Kapal penangkap ikan merupakan salah satu armada penangkapan yang digunakan nelayan untuk menuju ke fishing ground dan mengoperasikan alat tangkap (Azis et al., 2017) sehingga dapat memanfaatkan sumber daya perairan yang ada di lokasi. Adanya fungsi utama sebagai pencari, pengejar dan penangkap ikan menyebabkan kapal penangkap ikan harus memiliki komponenkomponen cukup optimal pada kapal dalam bekerja (Salam et al., 2017). Salah satu komponen yang sangat penting pada kontruksi kapal untuk bergerak dengan kecepatan tertentu di laut yaitu propeller (Kondo et al., 2012).

Propeller merupakan salah satu alat bantu penggerak kapal yang paling umum digunakan dalam menggerakkan kapal. Propeller pada kapal merupakan komponen penting untuk menggerakkan kapal dan memainkan peran dan fungsi utama sistem propulsi kapal. (Ishak et al., 2017). Efisiensi propeller sangat berpengaruh pada kinerja pada kapal. Efisiensi propeller dipengaruhi oleh desain dari propeller itu sendiri. Propeller dalam keadaan tertentu harus memiliki desain yang dapat menyerap daya seminimal mungkin dan memberikan efisiensi terhadap karakteristik dari tahanan kapal yang diberikan (Carlton, 2007). Propeller pada kapal adalah alat penggerak yang paling umum di kapal karena dapat memberikan momentum pada fluida sehingga dapat menyebabkan gaya dorong yang dapat menggerakkan kapal tersebut. Oleh karena itu, kerusakan yang banyak terjadi pada propeller disebabkan oleh deformasi yang sangat besar, patah kelelahan dan erosi disebabkan aliran fluida yang membawa padatan. Letak patahan tersebut banyak terjadi pada bagian blade propeller. Permukaan dari blade propeller merupakan bagian yang kontak langsung dengan fluida dan terjadinya fouling sehingga mengalami pembebanan yang menghasilkan kerusakan (Lee et al., 2002). Jenis kegagalan pada propeller akibat beban yang berulang-ulang atau berubah-ubah yang diperkirakan memiliki pengaruh 50\%-90\% dari kegagalan mekanis. Jenis kegagalan tersebut dibedakan menjadi dua kategori yaitu modus kegagalan yang tergantung oleh waktu dan modus kegagalan quasi static. Jenis kegagalan yang dikarenakan waktu antara lain kelelahan, mulur, keausan dan korosi. Sedankan jenis kegagalan quasi static yaitu kegagalan akibat beban fatik, tekan dan geser (Salam et al., 2017). Hasil wawancara dengan nelayan di lapangan beberapa kapal yang memiliki karakteristik yang sama dengan jumlah sekali trip sekitar 2 hingga 5 hari selalu memiliki masalah dengan propeller kapal setelah penggunaan kisaran 3,5 tahun hingga 4 tahunan yang seharusnya memiliki umur range 5 tahunan. Standar umur pakai propeller selama 5 tahunan tersebut sesuai dengan rata-rata umur pakai yang dikeluarkan perusahaan manufaktur propeller (Riza et al., 2012). Masalah pada propeller nelayan sering terjadi pada retak blade bagian dalam, patah blade, dan keausan pada bantalan propeller. Namun, lebih dari 50\% kegagalan propeller yang terjadi pada blade yaitu retak dan patah. Kegagalan yang disebabkan patah pada propeller sangat berbahaya bagi kapal tersebut. Sehingga hal tersebut membuat desainer perlu adanya tututan untuk mencegah kerusakan pada propeller. Disisi lain, penelitian tentang umur kelelahan yang disebabkan lingkungan kerja dan beberapa faktor yang menyebabkan adanya deformasi yang berlebih masih kurang (Yoon et al., 2009). Beberapa penelitian yang berhubungan dengan prediksi kerusakan pada propeller antara lain tentang analisis struktur propeller kapal (Lee et al., 2002) dan studi tentang kekuatan kelelahan pada propeller (Kim \& Kang, 2004). Beberapa penelitian tentang umur kelalahan dari propeller menunjukkan adanya beberapa permasalahan pada desain tersebut.

Kapal penangkap ikan membutuhkan sistem propulsi untuk bergerak maju pada lautan, sehingga dengan menggunakan mekanisme penghasil gaya dorong kapal dapat bergerak. Beberapa alat bantu untuk mendorong kapal yang sudah ada seiring 
dengan perkembangan teknologi saat ini yaitu propeller, pompa jet, jet air dan lain-lain yang dapat menghasilkan kecepatan pada kapal. Kecepatan kapal tergantung dengan pemilihan sistem propulsi kapal itu sendiri. Propeller sangat berhubungan dengan kinerja mesin utama kapal (Wanqing et al., 2011) yang mentransformasikan gaya yang ada. Gaya dorong yang berasal dari propeller dipindahkan untuk menggerakkan kapal melalui sistem transmisi yang terdiri dari gerakan rotasi yang dihasilkan oleh poros engkol dari mesin penggerak utama, poros tengah dan bantalannya, poros tabung buritan dan poros bantalan yang terhubung langsung oleh propeller. Rotasi yang dilakukan oleh propeller menciptakan gaya dorong untuk menggerakkan kapal. Hal tersebut menyebabkan adanya kelemahan struktur blade dari propeller yang disebabkan terjadinya aktivitas pada blade tersebut. Blade pada propeller sering terjadi yaitu erosi permukaan blade, pengurangan ketebalan blade dan permukaan pitch. Ilustrasi kurangnya kemampuan untuk mencegah kegagalan karena gaya yang tidak seimbang saat sistem propulsi bekerja. Hal tersebut dapat dijelaskan dengan menggunakan tegangan geser secara mekanis (Ishak et al., 2017). Tegangan geser pada daerah pada blade dapat di tunjukkan dengan persamaan sebagai berikut:

$$
\tau=\frac{F}{A}
$$

Keterangan

$\tau \quad:$ tegangan geser $\left(\mathrm{N} / \mathrm{mm}^{2}\right)$

$\mathrm{F}$ : gaya yang bekerja pada permukaan $(\mathrm{N})$

A : Daerah bagian melintang pada blade $\left(\mathrm{mm}^{2}\right)$

Gaya geser yang terjadi disebabkan adanya gaya torsi yang dipengaruhi oleh hydrostatic pressure merupakan pembebanan utamanya pada pembebanan hidrodinamik. Hal tersebut dikarenakan pada aplikasinya propeller bekerja berada dalam lingkungan fluida berupa air. Maka, tekanan hidrodinamik akan terjadi seiring dengan aliran fluida yang bekerja pada propeller dengan kecepatan tertentu yang kemudian menghantam bagian blade propeller (Salam et al., 2017). Pengaruh gaya hidrodinamika di sekitar propeller mempengaruhi dari karakteristik pembebanan dari propeller. Pembebanan propeller sendiri dapat ditampilkan dengan beberapa faktor ukuran propeller dan koefisien yang mempengaruhi propeller dalam diagram. Diagram tersebut dipengaruhi adanya Torque dan Thrust (gaya dorong kapal yang melawan gaya hidrodinamika) sebagai fungsi kecepatan. Karakteristik propeller terdiri dari koefisien Thrust $\left(K_{T}\right)$ dan koefisien
Torque $\left(K_{Q}\right)$ serta koefisien Advanced $(J)$. (Salam et al., 2017)

$$
\begin{aligned}
& J=\frac{V a}{n \cdot D} \\
& K_{T}=\frac{T}{\rho \cdot \pi^{2} \cdot D^{4}} \\
& K_{Q}=\frac{Q}{\rho \cdot \pi^{2} \cdot D^{5}}
\end{aligned}
$$

Keterangan

$$
\begin{array}{ll}
V a & : \text { Kecepatan Advanced }(\mathrm{fr} / \mathrm{s}) \\
\mathrm{n} & : \text { Putaran Propeller }(\mathrm{rev} / \mathrm{s}) \\
\mathrm{D} & : \text { Diameter Propeller }(\mathrm{ft}) \\
\mathrm{T} & : \text { Thrust Propeller }(\mathrm{lbf}) \\
\mathrm{Q} & : \text { Torque Propeller }(\mathrm{lbf} . \mathrm{ft}) \\
\rho & : \text { Masa Jenis Fluida }\left(\mathrm{S}^{2} / \mathrm{ft}^{4}\right)
\end{array}
$$

Umur kelalahan pada propeller sangat diperhatikan karena hal tersebut mempengaruhi dari umur pakai propeller tersebut. Prediksi umur kelelahan dari suatu komponen sangat dipengaruhi oleh kekuatan lelah dari bahan penyusun tersebut. Kelelahan bahan merupakan kondisi bahan mengalami retak atau rusak sebagai akibat pengaruh fluktuasi dari tegangan kerja secara terus menerus di bawah kekuatan luluh dari bahan tersebut (Setiyono, 2013). Umur kelelahan dari suatu material dapat diketahui dengan menggunakan pengujian beban secara terus menerus. Penggunaan kurva S-N digunakan untuk mendapatkan hasil dari perhitungan kelelahan. Hal tersebut untuk metode secara eksperimental. Kurva S-N mengambil pembebanan tegangan (S) dari spesimen standar dari bahan sebagai sumbu ordinat dan jumlah siklus (N) sebagai sumbu absis (Yu et al., 2014). Kurva S$\mathrm{N}$ dapat ditunjukkan pada Gambar 1.

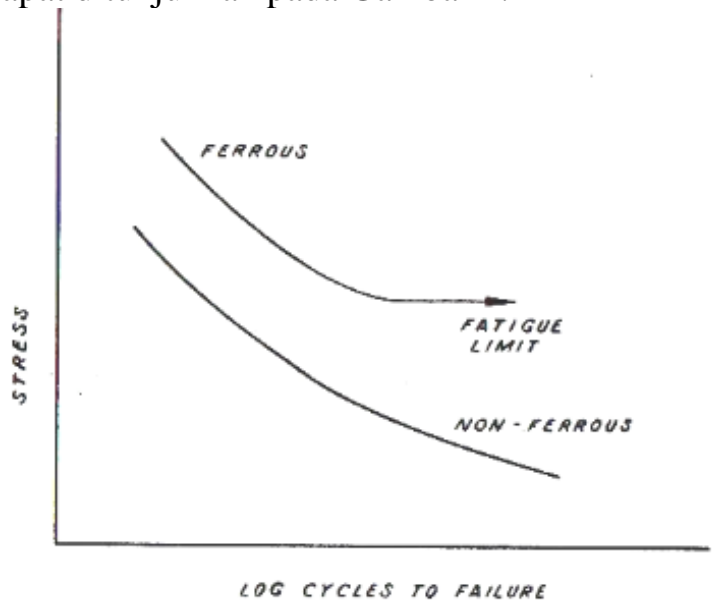

Gambar 1. Diagram S-N (Ridho et al., 2015)

Tingkat tegangan yang digunakan digambarkan dengan persamaan sebagai berikut:

$$
R=\frac{S_{\min }}{S_{\max }}=\frac{S_{m}-S_{a}}{S_{m}-S_{a}}
$$




$$
S_{a}=\frac{S_{\max }-S_{\min }}{2}
$$

$\mathrm{S}_{\max }$ merupakan nilai maksimum dari pembebanan sedangkan $S_{\min }$ merupakan nilai minimum pada pembebanan serta $S_{a}$ nilai tegangan rata rata (Gang et al., 2019). Penentuan umur dari propeller sendiri dapat dihitung dengan menggunakan perhitungan First-order stress cycle. First-order stress cycle merupakan tegangan yang diterima oleh balingbaling selama 1 kali putaran baling-baling tersebut. Sehingga dapat di tentukan bahwa perhitungan umur pakai material propeller dapat menggunakan persamaan berikut (Ridho et al., 2015):

First-Order fatigue cycle $=$

Rpm $x 60$ minutes $x 24$ hours $x$ operating days in one year

Perkembangan teknologi yang sangat pesat membuat seluruh analisis secara komputasi sangat pesat penggunaanya (Prasetiyo et al., 2019) (Prasetiyo et al., 2019). Sistem komputasi dapat menghitung umur kelelahan dengan metode permodelan suatu geometri. Perhitungan secara detail dalam memprediksi umur kelelahan dari suatu model sangat sulit untuk di hitung secara akurat. Finite Element analysis adalah salah satu metode secara numerik yang telah menjadi solusi untuk memprediksi akibat gaya yang bekerja pada suatu model secara teoritis dan mendetail (Rahmi et al., 2018) (Fadiji et al., 2018). Beberapa penelitian meneliti tentang umur pakai dari propeller. salah satunya penelitian tentang analisis statis menggunakan software CATIA V5R20, FLUENT dan ANSYS. Analisis pada propeller dengan variasi bahan yaitu $R$ Glass, $S 2$ Glass dan CRFP (Carbon Fiber Reinforced Plastics) yang menganalisis tegangan statis. Hasil yang didapatkan yaitu material dengan gaya paling minimum pada material aluminium dan R Glass Epoxy (Kumar et al., 2003). Penelitian yang lain meneliti tentang adanya analisis kegagalan struktur pada propeller blade marine. Analisis kekuatan quasy-steady pada propeller blade menggunakan Finite Element Method. Hasil yang didapatkan yaitu dengan kondisi tersebut mengidentifikasi bahwa angka keaman pada model sekitar 18-20 yang menyebabkan kegagalan pada geometri propeller (Lee et al., 2002). Penelitian lain meneliti tentang penentuan umur kelelahan pada permukaan propeller menggunakan Finite Element Analysis. Permodelan propeller menggunakan CATIA dan analisis menggunakan ABAQUS. Hasil yang diperoleh dalam penelitian ini yaitu analisis statis dan dinamis merkomendasikan bahwa dengan bahan carbon UD/ Epoxy sangat cocok untuk fabrikasi propeller (Rao et al., 2016).

Berdasarakan permasalahan yang sudah dipaparkan diatas maka penelitian tentang analisis umur kelelahan pada propeller kapal penangkap ikan pengaruh pembebanan hasil gaya dorongan atau gaya thrust dengan menggunakan Finite Element Analysis (FEA). Analisis tersebut digunakan untuk memprediksi umur kelelahan dan dampak dari pembebanan pada propeller kapal penangkap ikan di Kota Dumai.

\section{METODE}

Proses dari penelitian ini dapat dijelaskan dengan diagram alir yang ditunjukkan pada Gambar 2.

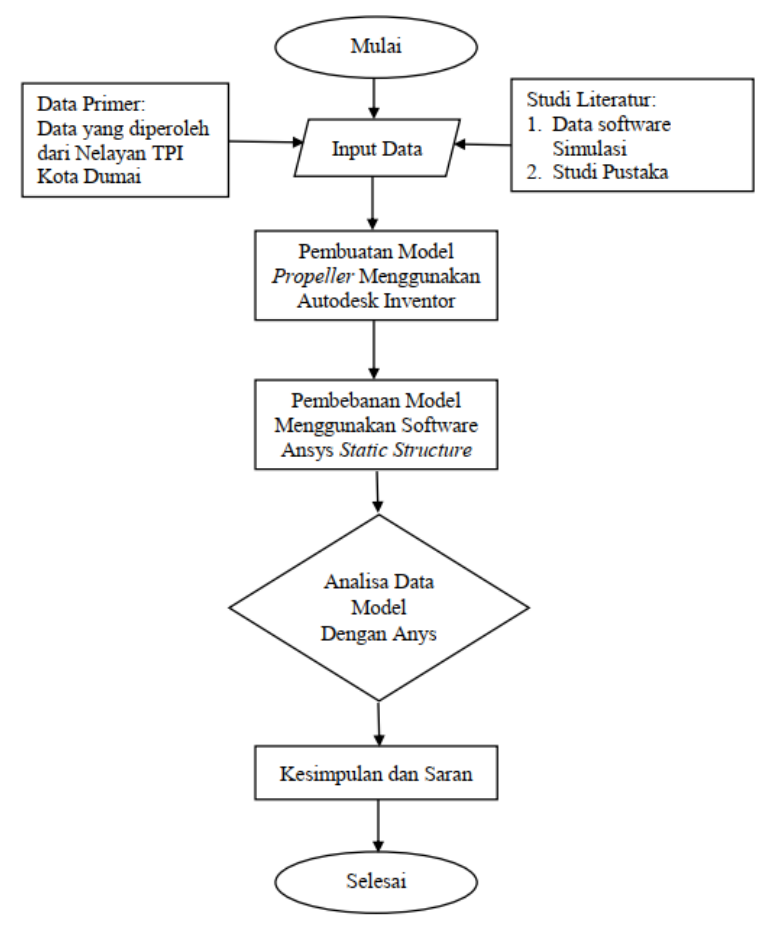

Gambar 2. Diagram alir penelitian

Tabel 1. Sifat mekanik paduan tembaga propeller (ASM Hanbook Vol 2, 1998)

\begin{tabular}{cc}
\hline Sifat & Nilai \\
\hline Densitas & $8,96 \mathrm{gr} / \mathrm{cm}^{3}$ \\
Modulus young & $128 \mathrm{GPa}$ \\
Poisson ratio & 0,34 \\
Yield strength & $70 \mathrm{Mpa}$ \\
Tensile strength & $220 \mathrm{Mpa}$ \\
Shear modulus & $47,76 \mathrm{Gpa}$ \\
Sifat & Isotropik \\
\hline
\end{tabular}

Bahan yang digunakan dalam model propeller pada kapal penangkap ikan yaitu paduan tembaga. Bahan tersebut digunakan karena memiliki 
kekuatan mekanik yang baik, keuletan yang baik mudah untuk dibentuk machining serta pengecoran. Selain itu, paduaan tembaga tahan terhadap erosi dan korosi di lingkungan laut. Sifat mekanik pada paduan temabaga yang digunakan dapat dinyatakan pada Tabel 1.

Tabel 2. Parameter yang digunakan pada fatigue test untuk paduan tembaga (Farshbaf et al., 2015)

\begin{tabular}{cc}
\hline Cycles $(\mathbf{N})$ & $\begin{array}{c}\text { Alternating Stress } \\
(\mathbf{P a})\end{array}$ \\
\hline 368 & $4 \times 10^{8}$ \\
953 & $3,75 \times 10^{8}$ \\
2800 & $3,5 \times 10^{8}$ \\
13000 & $3,25 \times 10^{8}$ \\
37000 & $3 \times 10^{8}$ \\
$1,3 \times 10^{5}$ & $2,75 \times 10^{8}$ \\
$5,9 \times 10^{6}$ & $2,5 \times 10^{8}$ \\
$2,4 \times 10^{7}$ & $2,25 \times 10^{8}$ \\
$1 \times 10^{8}$ & $2 \times 10^{8}$ \\
$1 \times 10^{9}$ & $1,99 \times 10^{8}$ \\
\hline
\end{tabular}

Paduan tembaga memiliki nilai parameter pengujian kelelahan yang terdiri dari jumlah siklus dan tegangan yang diijinkan. Parameter pengujian kelelahan dikutip dari penelitian yang telah dilakukan secara eksperimental dari pengujian bahan paduan tembaga tersebut. Parameter pengujian kelelahan sangat penting untuk ditampilkan karena sangat memperngaruhi dari hasil permodelan dari hasil nilai kelelahan tersebut. Parameter pengujian kelelahan ditunjukkan pada Tabel 2.

Tabel 3. Geometri bentuk dari propeller kapal penangkap ikan

\begin{tabular}{cc}
\hline Geometri & Nilai \\
\hline Diameter dalam lubang poros & $31,7 \mathrm{~mm}$ \\
Diameter luar lubang poros & $62,4 \mathrm{~mm}$ \\
Diameter propeller & $470 \mathrm{~mm}$ \\
Jumlah blade & 3 \\
Tebal dalam Blade & $13,7 \mathrm{~mm}$ \\
Tebal luar Blade & $4,7 \mathrm{~mm}$ \\
Panjang blade & $235 \mathrm{~mm}$ \\
Putaran propeller & Ke kanan \\
Pitch propeller & $246,6 \mathrm{~mm}$ \\
\hline
\end{tabular}

Gambar model propeller kapal penangkap ikan menggunakan software Inventor 2017. Data pengukuran propeller kapal penangkap ikan yang berada TPI Kota Dumai menjadi acuan pembuatan model secara 3D. Penentuan blade pada propeller menyesuaikan tinggi propeller dan pitch dari propeller tersebut. Bagian ini digambar mengelilingi bagian titik tengah dari propeller dan berputar searah dengan sudut pitch. Kemudian semua blade diproyeksikan sesuai dengan jumlah blade. Setiap sambungan blade diberikan filet untuk menyesuaikan keadaan lapangan. Parameter geometri gambar propeller penangkap ikan ditunjukkan pada Tabel 3.

Penentuan parameter pembebanan dilakukan dengan perhitungan secara matematis menggunakan beberapa kajian yang sudah dibahas sehingga mendapatkan gaya-gaya hidrodinamis yang menjadi pembebanan pada propeller kapal penangkap ikan. Gaya hidrodinamika ditransformasikan menjadi pembebanan yang diletakkan pada blade propeller kapal penangkap ikan. Parameter untuk menentukan gaya-gaya hidromekanika ditunjukkan pada Tabel 4. Data parameter tersebut sangat berkaitan dengan kondisi kapal ikan saat bergerak secara umum di wilayah perairan Kota Dumai. Pembebanan tersebut didistribusikan secara merata pada propeller kapal penangkap ikan yang menunjukkan pembebanan ketika saat kapal ikan bergerak.

Tabel 4. Parameter laju kapal ikan di perairan Kota Dumai

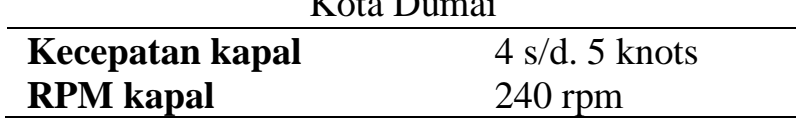

Proses simulasi dilakukan dengan menggunakan software elemen hingga yaitu ANSYS versi R.17.2. Proses simulasi dimulai dari penginputan model 3D yang sudah digambar dengan format *iges agar dapat diproses dalam software elemen hingga. Setalah itu proses mehing dilakukan dengan pemilihan mesh berbentuk tetrahedral yang halus. Pemilihan meshing ditunjukkan untuk memaksimalkan hasil dari simulasi. Hasil dari pemilihan tersebut mendapatkan jumlah number of element sebanyak 26268 sedangkan jumlah nodes yang digunakan dalam simulasi propeller kapal penangkap ikan yaitu berjumlah 51108. Hasil meshing dengan parameter tersebut dapat ditunjukkan pada Gambar 3.

Boundary condition yang digunakan pada simulasi propeller dengan pembebanan merata pada blade sebesar 9969,8 $\mathrm{N}$ yang didapat dari perhitungan nilai thrust (gaya dorong) serta fixed support pada bagian tengah propeller karena menjadi tumpuan saat propeller dikunci dengan poros yang tersambung dengan motor penggerak. Parameter yang telah dimasukkan kedalam software kemudian pemilihan penyelesaian pada simulasi propeller antara lain Total Deformation, Equivalent Stress, Life Fatigue, Safety Factor Fatigue, Damage 
Fatigue, dan Equivalent Alternating Stress. Hasil yang akan ditampilkan dari software elemen hingga yaitu struktur kontur dari pembebanan saat proses simulasi.

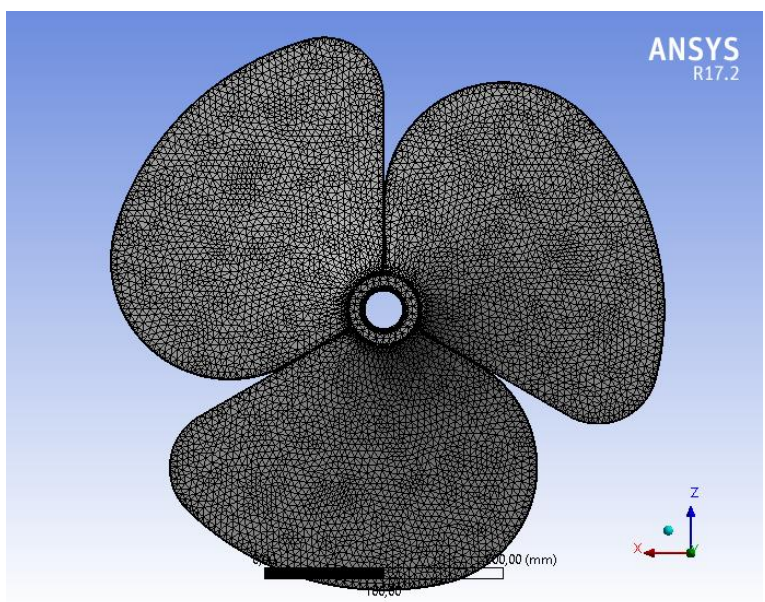

Gambar 3. Hasil meshing pada propeller kapal penangkap ikan Kota Dumai.

\section{HASIL DAN PEMBAHASAN}

Simulasi Finite Element Analysis menggunakan software ANSYS pada propeller kapal penangkap ikan diperoleh beberapa hasil parameter yang didapatkan. Sasaran dari penelitian ini yaitu umur kelelahan dari propeller kapal penangkap ikan saat beroperasi. Pengaruh pada tegangan rata-rata yang diijinkan pada umur kelelahan dapat dicari dengan diagram S-N (Bekheet, 2017). Tegangan Von Mises secara teoritis mempresentasikan nilai dari jumlah tegangan yang diterima saat proses simulasi propeller berlangsung. Selain itu tegangan Von Mises dapat menunjukkan inisiai dari terbentuknya kerugian yang terjadi dari pembebanan tersebut pada mode simulasi. Hasil dari simulasi permodelan tegangan Von Mises dapat ditunjukkan pada Gambar 4.

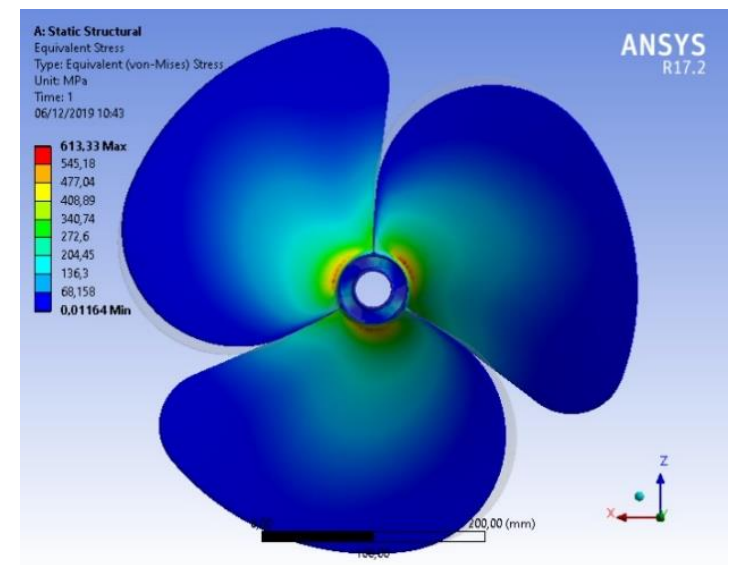

Gambar 4. Distribusi tegangan Von Mises pada propeller.
Tegangan Von Mises hasil simulasi permodelan propeller didapatkan nilai maksimum pada daerah antara sambungan blade propeller dan lubang poros dari propeller dengan nilai 613,33 MPa. Sedangkan tegangan Von Mises terendah terletak pada ujung blade dari propeller sebesar 0,01164 MPa. Gambar 4 menunjukkan adanya kontur distribusi dari tegangan Von Mises yang ditunjukkan menuju arah poros propeller. Tegangan Von Mises terbentuk dari gaya dorong yang secara langsung bekerja pada permukaan propeller. Sehingga terjadi perbedaan tekanan atau pembebanan dari setiap daerah permukaan. Hal tersebut didukung dengan adanya degradasi warna dari warna biru yang memiliki nilai terendah dan warna merah yang memiliki nilai tertinggi atau maksimum. Fenomena tersebut disebabkan adanya tumpuan jepit pada blade propeller yang menyebabkan tegangan terbesar akan terkonsentrasi pada titik yang terlemah. Titik terlemah tersebut berada pada titik sambungan antara blade dan poros propeller (Syafrizal, 2017) atau pada daerah root pada blade propeller yang menjadikan daerah tersebut daerah hot spot stress (Salam et al., 2017). Daerah dengan tegangan Von Mises terbesar menjadi daerah yang memiliki tingkat kritis yang besar karena pada daerah tersebut menerima beban yang sangat besar.

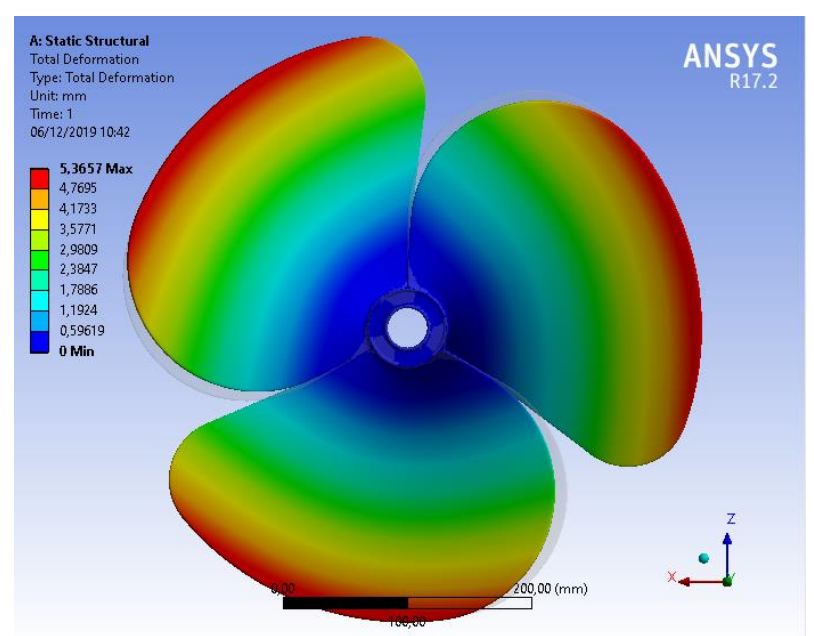

Gambar 5. Distribusi deformasi pada propeller

Pengaruh tegangan Von Mises yang terjadi pada propeller menyebabkan terjadinya deformasi. Hal tersebut merupakan hukum alam yang sering terjadi pada suatu bahan. Gambar 5. menunjukkan adanya kontur distribusi deformasi pada propeller. Deformasi tertinggi berada pada daerah ujung blade propeller yang ditandai dengan warna merah dengan nilai sejauh 5,3657mm pada arah sumbu y. Sedangkan deformasi terendah berada pada root pada blade propeller dengan ditandai warna biru dengan nilai deformasi blade propeller sejauh $0 \mathrm{~mm}$ 
pada arah sumbu y atau tidak terjadi deformasi. Perubahan bentuk dari suatu geometri benda yang dimodelkan dipengaruhi dengan distribusi gaya atau beban yang terjadi secara langsung pada model (Pranoto et al., 2018). Fenomena tersebut menunjukkan adanya pengaruh pembebanan merata pada blade propeller yang menyebabkan perubahan bentuk pada daerah yang terbebani paling besar. Kondisi yang terjadi pada simulasi model propeller mirip dengan kasus cantilever beam yang memiliki perubahan bentuk kearah sumbu vertikal (dalam kasus ini sumbu y) dengan nilai maksimum pada ujung bebas (Navya et al., 2018). Deformasi yang terjadi diperkuat dengan adanya persamaan elastis Bernoulli-Euler pada bahan (Samal et al., 2016). Persamaan tersebut yaitu:

$$
E I\left(\frac{d^{2} y}{d x^{2}}\right)=M
$$

Persamaan tersebut membuktikan bahwa adanya perubahan bentuk dari suatu bahan sangat tergantung pada sifat mekanik bahan tersebut dan bentuk geometri dari model.

Penentuan umur kelelahan pada propeller memiliki tujuan untuk mengetahu kekuatan dari desain propelleryang diaplikasikan pada pembebanan aplikatif. Penentuan umur kelelahan pada model propeller dapat disebabkan adanya pembebanan berulang secara langsung yang memiliki nilai di bawah tegangan luluh. Tingkat tegangan yang diaplikasikan pada model simulasi menjadikan dasar dari penentuan umur kelelahan pada model (Rao et al., 2016). Metode yang menjelaskan peristiwa tersebut yaitu metode stresslife. Hasil distribusi tegangan yang terjadi pada propeller menjadi acuan persebesaran umur kelelahan pada propeller.

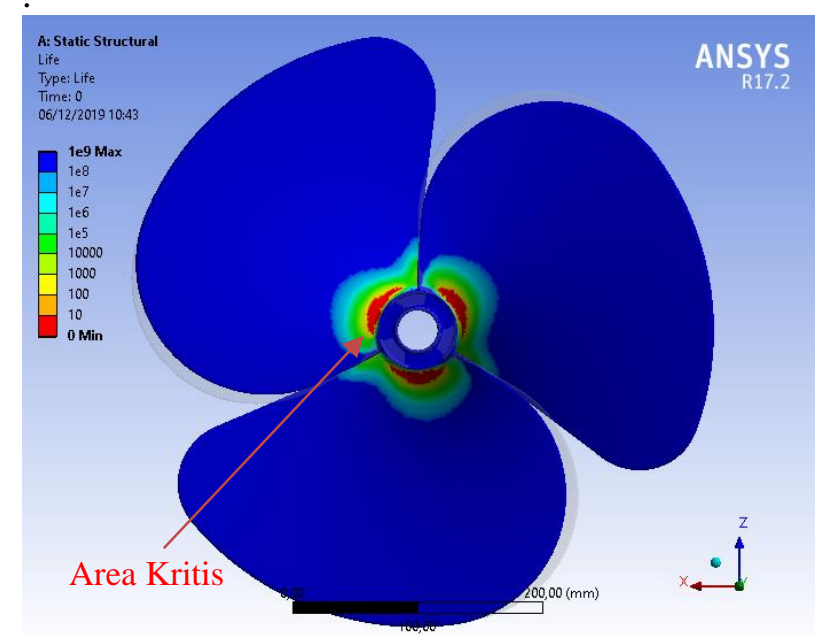

Gambar 6. Distribusi umur kelelahan (fatigue life) pada propeller
Gambar 6. menunjukkan adanya persebaran umur kelelahan pada propeller kapal penangkap ikan yang digunakan di Kota Dumai. Jumlah siklus fatigue life tertinggi dengan ditunjukkan warna biru pada hasil simulasi permodelan yaitu $10^{9}$ sedangkan paling rendah yang ditunjukkan dengan warna merah sebesar 0 . Hal ini sejalan dengan persebaran besar tegangan yang terjadi pada propeller. Dimana daerah dengan tegangan terbesar memiliki nilai umur kelelahan yang rendah begitupun sebaliknya, daerah dengan tegangan terendah memiliki umur kelahan yang sangat besar (Maulana et al., 2019). Analisa yang didapatkan yaitu adanya patah pada propeller ketika digunakan sebelum waktunya. Hal tersebut sangat sesuai dengan kejadian yang ada di lapangan. Beberapa nelayan yang ada di Kota Dumai yang menggunakan kapal penangkap ikan dengan model propeller tersebut sangat resah karena sering terjadi kegagalan. Selain itu, penelitian eksperimental yang divalidasi dengan penelitian permodelan menyatakan bahwa desain dan material propeller yang memiliki jumlah siklus di bawah $10^{8}$ akan mengalami keruskaan sebelum waktunya atau umur penggunaan yang sangat pendek (Ridho et al., 2015).

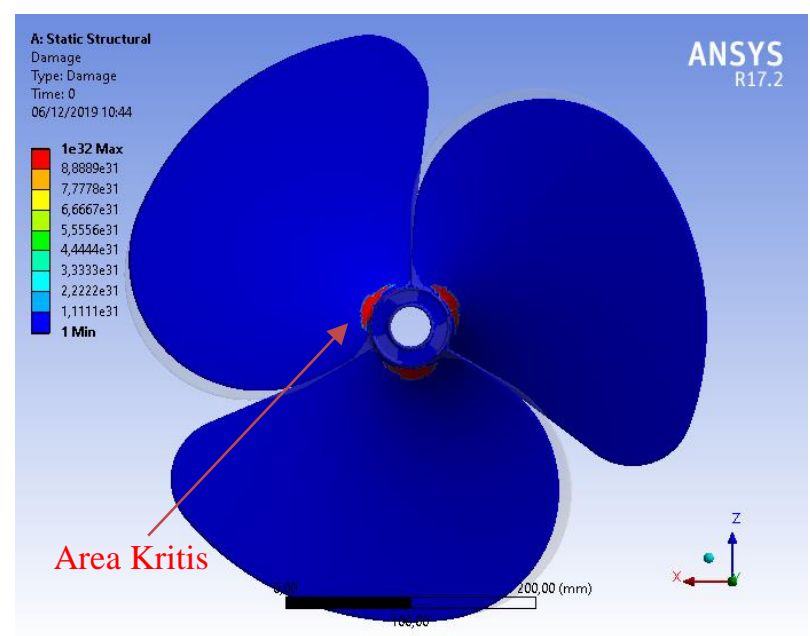

Gambar 7. Distribusi bahaya akibat analisis kegagalan pada propeller hasil simulasi.

Adanya distribusi tegangan, perubahan bentuk geometri dan sebaran umur kelelahan disekitar model propeller dapat menentukan tingkat bahaya kegagalan karena pembebanan yang akan terjadi di beberapa titik lemah pada propeller. Permodelan fatigue pada Finite Element Analysis dapat mengetahui beberapa daerah yang dapat menginisiasi bahaya yang disebabkan tegangan yang terjadi secara langsung. Gambar 7 . menunjukkan adanya distribusi bahaya pada propeller kapal penangkap ikan. Dimana nilai terbesar berada pada daerah sambungan poros 
tengah propeller atau daerah root propeller dengan warna merah yang memiliki besaran nilai tingkat bahaya terjadinya kegagalan model sebesar $10^{32}$. Hal tersebut menunjukkan tingkat bahaya pada desain propeller yang sangat bahaya. Sedangkan tingkat bahaya pada ujung blade pada propeller sangat rendah dengan ditandai warna biru yang memiliki besaran tingkat bahaya 1 . Tingkat bahaya pada model simulasi sangat dipengaruhi adanya tegangan yang bekerja pada model tersebut. Tegangan tengah (mean stress) merupakan salah satu penyebab terjadinya bahaya secara kumulatif (Gang et al., 2019). Selain itu, kontur dari hasil simulasi permodelan bahaya sangat mirip letak tingkat bahaya dengan daerah yang dihasilkan pada simulasi permodelan umur kelelahan. Tingkat bahaya dapat memprediksi tingkat kerusakan dan letak kerusakan yang ada pada model simulasi pada propeller. Tingkat bahaya tersebut dapat berupa retak maupun patahan akibat pembebanan yang berulang-ulang.

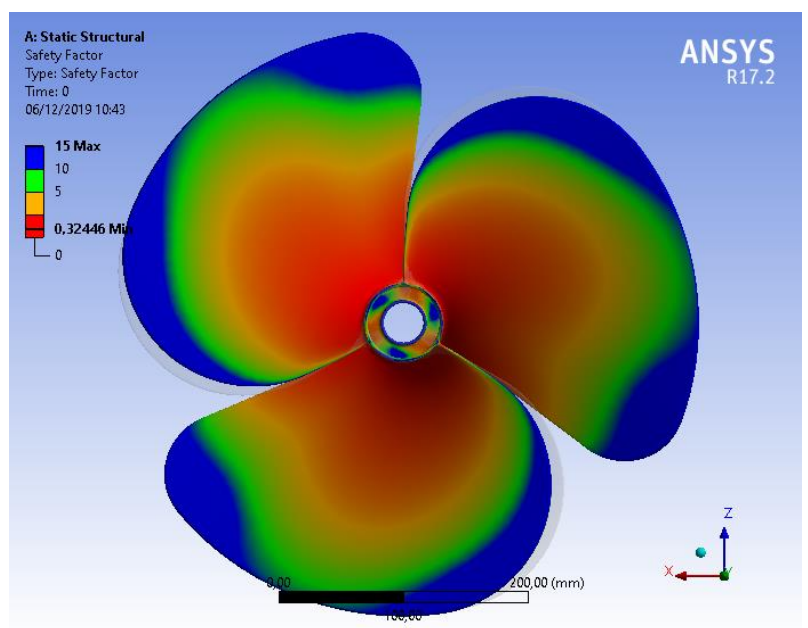

Gambar 8. Safety factor pada propeller hasil simulasi

Analisa tingkat keamaan pada perancangan sangat mempengaruhi hasil dari kualitas aman perancangan suatu model tersebut (Setyono et al., 2016). Safety factor atau angka keamanan merupakan perbandingan antara tegangan yang diijinkan dengan tegangan yang terjadi pada model simulasi. Gambar 8. menunjukkan distribusi angka keamaan pada simulasi propeller pada kapal penangkap ikan. Tingkat angka keamaan pada propeller berada pada ujung blade bagian sisi pinggir dengan ditandai warna biru dengan besaran tingkat angka keamaan yaitu 15 . Sedangkan daerah sambungan blade propeller dengan poros propeller atau root propeller memiliki angka keamanan yang sangat kecil yaitu 0,32446. Model simulasi akan dinyatakan aman apabila angka keamanannya lebih dari satu (Setyono et al., 2016). Semakin tinggi nilai dari angka keamanannya maka tingkat keamanan yang dimiliki oleh model struktur ketika menerima beban adalah semakin baik. Adanya hasil simulasi permodelan propeller yang memiliki angka dibawah satu menyebabkan model propeller yang digunakan sangat riskan dipakai atau tidak aman. Jika faktor keamanannya kurang dari 1,0 maka model dapat mengalami deformasi plastis yang akan berdampak terhadap ketidakmampuan suatu model struktur menahan beban yang terjadi. Hal tersebut menyebabkan kegagalan yang terjadi propeller tidak dapat diprediksi.

\section{PENUTUP}

\section{Kesimpulan}

Berdasarkan hasil simulasi permodelan dan pembahasan umur kelelahan pada propeller kapal penangkap ikan dapat disimpulkan bahwa bentuk model dan geometri dari propeller kapal penangkap ikan di Kota Dumai memiliki umur kelelahan paling rendah yaitu 0. Nilai tersebut berada pada daerah root propeller atau daerah dekat dengan poros propeller. Dimana keadaan tersebut menyebabkan propeller dengan desain geometri tersebut mengalami kegagalan atau patah sebelum waktunya. Fenomena tersebut sangat berpengaruh dengan tingkat keamanan (safety factor) pada propeller. Tingkat keamanan yang rendah dan dapat menyebabkan kegagalan sebelum waktunya. Nilai keamanan didapat berdasarkan simulasi model propeller paling rendah yaitu 0,32446. Nilai keamanan yang lebih rendah dari 1 menyebabkan desain tersebut tidak aman. Beberapa pernyataan tentang umur pakai dan tingkat keamanan sangat relevan dengan keadaan lapangan. Dimana kebanyakan nelayan mengalami kerusakan pada propeller mereka sebelum pekerjaan perbaikan untuk kapal dilakukan. Sehingga, dapat dikatakan adanya kesinambungan tersebut dapat menjadikan alasan secara ilmiah.

\section{Saran}

Perbaikan atau modifikasi desain dari propeller yang sangat efektif dalam pembebanan akibat pergerakan kapal. Hal tersebut dapat menjawab solusi dari permaslahan yang sering dialami oleh masyarakat karena propeller kapal yang patah sebelum waktunya. Selain itu, adanya perbedaan material menjadi acuan untuk menentukan jenis propeller yang efektif dalam perairan Kota Dumai. 


\section{Ucapan Terima Kasih}

Ucapan terima kasih diberikan kepada pihak nelayan di daerah Tempat Pelelangan Ikan Purnama Kota Dumai yang telah memberikan ijin untuk mengambil data propeller kapal. Ucapan terima kasih juga di ucapkan kepada saudara Rudi Efendi dan Mhd. Rahman yang telah membantu peneliti dalam pelaksanaan pengambilan data di lokasi.

\section{DAFTAR PUSTAKA}

Azis, M. A., Iskandar, B. H., \& Novita, Y. (2017). Kajian Desain Kapal Purse Seine Tradisional Di Kabupaten Pinrang (Study Kasus Km. Cahaya Arafah). ALBACORE, I(1), 69-76.

ASM Handbook Vol 2 (1998). Properties and selection: Nonferrous Alloys and SpecialPurpose Materials. In ASM Handbook Committe, United States

Carlton, J. (2007). Marine Propellers and Propulsion (Third Edit, Issue 1). Elsevier Ltd.

Fadiji, T., Coetzee, C. J., Berry, T. M., Ambaw, A., \& Opara, U. L. (2018). The efficacy of finite element analysis (FEA) as a design tool for food packaging: A review. Biosystems Engineering, 174, 20-40.

Farshbaf, P., \& Habibi, F. (2015). Fatigue properties of $\mathrm{Al} 2 \mathrm{O} 3$ reinforced $\mathrm{Cu}$. International Conference Irian Metallurgical \& Materials Engineering Society, 4(November).

Gang, L., \& Yong, S. (2019). Fatigue Life Calculation of Shaft System Based on BendTorsion Coupling Fatigue Life Calculation of Shaft System Based on Bend- Torsion Coupling. IOP Conference Series: Materials Science and Engineering, 569(022008), 1-6.

Ishak, M. A., Sulaiman, S., Baharudin, B. T. H. T., \& Syajaratunnur, Y. (2017). Research on the ship propeller blade to determine changes in the mechanical properties based on the forces projection. ARPN Journal of Engineering and Applied Sciences, 12(4), 1241-1247.

Kim, J.-H., \& Kang, N.-H. (2004). A Study on the Fatigue Strength of Highly Skewed Propeller. Journal of the Korean Society of Marine Engineers, 28(7), 1131-1137.

Kondo, Y., Siahaya, Y., \& Leonard, J. (2012). Analisis Investasi Pada Industri Pengecoran Propeller Kapal (Studi Kasus: Cv. Antero Jaya Sakti). Jurnal Mekanikal, 3(1), 231-239.

Kumar, H., Singh, S., \& Kumar, P. (2003). Effects of $\mathrm{s}$ urfaces $\mathrm{n}$ anocrystallization induced by $\mathrm{s}$ hot $\mathrm{p}$ eening on material properties : a Review. International Journal of Engineering Sciences \& Emerging Technologies, 5(1), 12-19.
Lasabuda, R. (2013). Pembangunan Wilayah Pesisir Dan Lautan Dalam Perspektif Negara Kepulauan Republik Indonesia. Jurnal Ilmiah Platax, I(2), 92-101.

Lee, C.-S., Kim, Y.-J., Kim, G.-D., \& Nho, I.-S. (2002). Analysis of the Structural Failure of Marine Propeller Blades. Journal of Ship \& Ocean Technology, 6(3), 37-45.

Maulana, A., \& Ariatedja, J. B. (2019). Analisa Fatigue pada Rangka Sepeda Trandem dengan Menggunakan Metode Elemen Hingga. Jurnal Teknik ITS, 8(1), 48-53.

Navya, C., Nageswara, S., Kuladeep, G., Lakshmikala, K., \& Neeraja, S. (2018). Modelling And Analysis Of Propeller Blade For Marine Engine By Fea Approach. International Journal of Scientific Researc, 7(3), 216-225.

Pranoto, S. H., \& Mahardika, M. (2018). Design and finite element analysis of micro punch $\mathrm{CNC}$ machine modeling for medical devices. AIP Conference Proceedings, 1941.

Prasetiyo, A. B., Azmi, A. A., Pamuji, D. S., \& Yaqin, R. (2019). Pengaruh Perbedaan Mesh Terstruktur dan Mesh Tidak Terstruktur Pada Simulasi Sistem Pendinginan Mold Injeksi Produk Plastik. Prosiding Nasional Rekayasa Teknologi Industri Dan Informasi XIV Tahun 2019 (ReTII), 2019(November), 400-406.

Prasetiyo, A. B., Fauzun, Azmi, A. A., Yaqin, R. I., \& Pakpahan, B. M. (2019). Analisis Numerik Perpindahan Panas Pada Saluran Pendingin Plastik Injeksi Molding Menggunakan Polyhedral Mesh. Manutech: Jurnal Teknologi Manufaktur, 11(02), 70-79.

Rahmi, M., Canra, D., \& Suliono, S. (2018). Analisis Kekuatan Ball Valve Akibat Tekanan Fluida Menggunakan Finite Element Analysis. JTT (Jurnal Teknologi Terapan), 4(2), 79-84.

Rao, R., Mohan, S., \& Kumar, G. (2016). Determination of Fatigue Life of Surface Propeller by Using Finite Element Analysis. International Journal of Engineering Science, 2492(8), 2492-2503.

Ridho, M., Zakki, A. F., \& Manik, P. (2015). Analisa Fatigue propeller Tugboat Ari 400hp Dengan Metode Elemen Hingga. Jurnal Teknik Perkapalan, 3(1), 110-117.

Riza, M. F., \& Pribadi, T. W. (2012). Analisis Teknis dan Ekonomis Pembangunan Industri Manufaktur Baling - Baling Kapal di Indonesia. Jurnal Teknik ITS, 1(1), G-88-G93. Salam, H. A. H., Mulyatno, I. P., \& Iqbal, M. (2017). Analisa Kelelahan Propeller Kapal Ikan PVC Dengan Metode Elemen Hingga. 
Jurnal Teknik Perkapalan, 5(1), 243-252.

Samal, A. K., \& Rao, T. E. (2016). Analysis of Stress and Deflection of Cantilever Beam and its Validation Using COMSOL Multiphysics. International Journal of Engineering, Research \& Applications, 02(1), 119-126.

Setiyono, H. (2013). Standar Spesifikasi Desain Untuk Analisis Umur Lelah Pelat Baja Tahan Karat Akibat Beban Dinamis Aksial. Jurnal Standardisasi, 16(1), 57-64.

Setyono, B., Mrihrenaningtyas, \& Hamid, A. (2016). Perancangan Dan Analisis Kekuatan Frame Sepeda Hibrid “Trisona” Menggunakan Software Autodesk Inventor. Jurnal IPTEK, 20(2), 37.

Syafrizal. (2017). Analisis tegangan batang lentur tumpuan jepit dan roll pada material stainless stell. ELEKTRA, 2(2), 93-100.

Wanqing, W. U., Hongcun, Z., \& Xing, F. (2011). Study of Ship Propeller Cut and Effecting on Main Engine Running Parameters. Advanced Materials Research, 297, 603-609.

Yoon, H., \& Zhang, J. (2009). Prediction of fatigue life distribution of marine propeller materials. Journal of Mechanical Science and Technology, 23, 1323-1330.

Yu, Z., \& Xu, X. (2014). Fatigue Fracture of a Locomotive Diesel Engine Cardan-Shaft. Journal of Failure Analysis and Prevention, 14(3), 405-411. 